\title{
Computational Study of the Molecular Complexes between 5-HTP with ATP and DHEA. Potential New Drug Resulting from This Complexation
}

\author{
Dan A. Lerner ${ }^{1}$, Constantin Balaceanu-Stolnici ${ }^{2}$, Josette Weinberg ${ }^{3}{ }^{*}$, Luminita Patron ${ }^{3}$ \\ ${ }^{1}$ Institut Charles Gerhardt Montpellier, Montpellier, France \\ ${ }^{2}$ Ecological University of Bucharest, Bucharest, Romania \\ ${ }^{3}$ Institute of Physical Chemistry, Bucharest, Romania \\ Email: ${ }^{\text {josettecarline@yahoo.com }}$
}

Received 20 December 2014; accepted 10 January 2015; published 16 January 2015

Copyright @ 2015 by authors and Scientific Research Publishing Inc.

This work is licensed under the Creative Commons Attribution International License (CC BY). http://creativecommons.org/licenses/by/4.0/

c) (i) Open Access

\begin{abstract}
Extending the potential interest in new drugs resulting from the association of biologically important molecules in stable complexes, the present study shows that this concept previously implemented in the case of two components could be a meaningful and promising one in the case of three components. The choice was made here to show that the quantum chemical modeling of a tripartite complex with DHEA (DEHYDRO-EPIANDROSTERONE) in a ternary association with 5-hydroxytryptophan (5-HTP) and adenosine triphosphate acid (ATP) could have a sizable stability.
\end{abstract}

\section{Keywords}

\section{5-HTP, ATP, DHEA, Density Functional Theory (DFT)}

\section{Introduction}

In the previous decade, literature references have emphasized the fact that DHEA is the active form of a steroidal hormone, with very desirable physiological and beneficial health properties in animals and humans. Furthermore, the advances made in various areas of chemistry with the help of the supramolecular paradigm emphasize the importance of a theoretical analysis of intermolecular interactions in relevant associations of weakly bound biologically active molecules. The present paper targets such a goal by characterizing DHEA, generated in the su-

"Corresponding author.

How to cite this paper: Lerner, D.A., Balaceanu-Stolnici, C., Weinberg, J. and Patron, L. (2015) Computational Study of the Molecular Complexes between 5-HTP with ATP and DHEA. Potential New Drug Resulting from This Complexation. Computational Chemistry, 3, 18-22. http://dx.doi.org/10.4236/cc.2014.31003 
prarenal glands and in the brain, in a ternary association with 5-hydroxytryptophan (5-HTP) and adenosine triphosphate acid (ATP). 5-HTP is the precursor of the neurotransmitter serotonin (which became very popular for the following single reason: people felt better when they used it) while ATP is the major source of energy in the human organism. The existence of such a complex association could constitute a new and interesting drug. The concept of potential new drugs resulting from supramolecular associations was previously exposed by the authors in the case of two components drugs and is extended here [1]-[4]. Molecular parameters of DHEA 5-HTP and ATP and of their putative three-component complex, including its heat of formation, have been computed in an $a b$ initio study involving DFT calculations. The aim of this study is to emphasize the possible existence of a complex between DHEA, 5-HTP and ATP that may have the properties of a new important drug.

\section{Methods}

The initial geometry input for 5-HTP, ATP and DHEA was obtained from a molecular mechanics calculation $(\mathrm{MM}+$ force field) [5]. The resulting molecular geometries were optimized without any constraints. Next, $a b$ initio calculations were carried out using the Gaussian 09 program [6]. The geometries of ATP, 5-HTP and DHEA, and of their complex were optimized at the $3-21 \mathrm{G}^{*}$ level, starting from an INDO guess. A stationary point was found. At this stage, a refinement was carried out by a single point calculation at the B3LYP/6-31G* level [7]. The structure of the molecules under consideration is presented in Scheme 1.

\section{Results and Discussion}

\subsection{Structure and Bonding in the Molecular Units and Their Intermolecular Complex}

The formation of the ATP-5-HTP-DHEA complex is analyzed in terms of geometry, charge and energy parameters. The different nature of the overall molecular constitution of the three biomolecules, ATP, DHEA and 5-HTP which possess essentially a planar $\pi$-conjugated core, practically precludes a significant association of the $\pi-\pi$ stacking type. The strongest association forces involve hydrogen bonds. There are of course several possible patterns for hydrogen bonding $(\mathrm{O}-\mathrm{H} \cdots \mathrm{O}, \mathrm{O}-\mathrm{H} \cdots \mathrm{N}$, involving the various heteroatom combinations). The supramolecular association presented here is the optimal one due to the supplementary stabilization resulting from the alignment of the dipoles on the molecular constituents (Table 1 ).

In this complex 5-HTP is not interacting directly with ATP as in a binary complex previously described. Another difference for the two complexes is the fact that the association energy of the tripartite complex is very high at this computational level compared to that of the binary complex. This is in favor of the possible existence of such a complex. For instance, the fact that DHEA is sandwiched between ATP and 5-HTP is interesting as DHEA is the most hydrophobic of the 3 components and it would be shielded from contact with water. Of course, this modeling corresponds to data obtained at 0 degree $\mathrm{K}$ in the vacuum and the presence of water as a

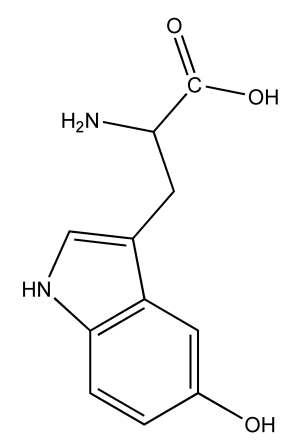

5-Hydroxytryptophan (5-HTP)

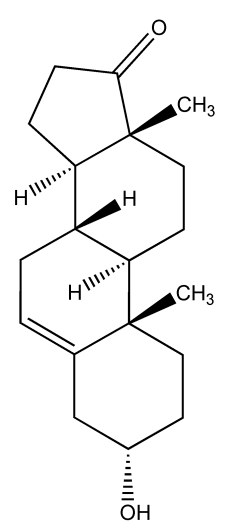

Dehydroepiandrosterone (DHEA)

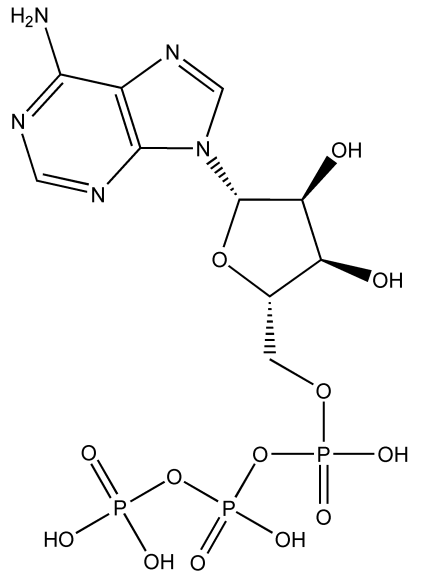

Adenosine triphosphate (ATP)

Scheme 1. The structure of the molecules involved in the present study: 5-Hydroxytryptophan (5-HTP); Dehydroepiandrosterone (DHEA); Adenosine triphosphate (ATP). 
solvent would heavily perturb the structure. However, as ATP disodium salt for instance is not very water soluble $\left(50 \mathrm{mg} \cdot \mathrm{L}^{-1}\right)$, and furthermore 5 -HTP is only slightly soluble while DHEA is hardly soluble $\left(63.5 \mathrm{mg} \cdot \mathrm{L}^{-1}\right.$ at $25^{\circ} \mathrm{C}$ ), the tripartite association could resist its immersion in water or in a buffer.

In the body, absorption of 5-HTP occurs by an active transport process. 5-Hydroxytryptophan is decarboxylated to serotonin (5-hydroxytryptamine or 5-HT) by the enzymearomatic-L-amino-acid decarboxylase with the help of vitamin B6 [7]. This reaction occurs both in nervous tissue and in the liver [7]. The psychoactive action of 5-HTP is derived from its increase in production of serotonin in central nervous system tissue [7].

The bonding associations $\mathrm{O}(47) \cdots \mathrm{H}(102)$ from DHEA-ATP and $\mathrm{O}(25) \cdots \mathrm{H}(67)$ from 5-HTP-DHEA reveal abond length in the expected range for the given type, $1.5284 \AA$ and $2.84369 \AA$ respectively. The geometry of the complexis further characterized by the $\mathrm{O} 47 \cdots \mathrm{H} 102-\mathrm{N} 100$ angle and $\mathrm{O} 111 \cdots \mathrm{H} 74-\mathrm{C} 27$ angle values $\left(155.669^{\circ}\right.$ and $157.52^{\circ}$ respectively). DFT results can be credited with a higher confidence in the quantitative respects because of their partial treatment of correlation effects. On the other hand, it is acknowledged that the regular DFT functionals face intrinsic problems in the long-range regime [1].

It is seen in Table 2 that atom O111 from ATP acquires the largest negative charge in B3LYP calculations. A larger positive increase of the charge is noted for the hydrogen from the bridge hydrogen with DHEA, H67. The effect of such an association would then result in an activation of ATP and DHEA induced by that electronic distribution change. The effect of such charge displacements in the complex would then result in some activation of ATP and DHEA, and in their activity. In which case, a new drug could be obtained.

\subsection{Frontier Molecular Orbitals}

The frontier molecular orbitals (FMO) are the highest molecular orbitals (HOMO) and the lowest-lying unoccupied molecular orbitals (LUMO) [8]-[10]. The FMOs play an important role in modeling spectra and chemical reactions [10]. Here the HOMO is localized on the adenine part of the adenosine molecule belonging to ATP and on the carbonyl oxygen of DHEA whereas the LUMO is delocalized on almost the whole 5-HTP molecule (Table 3 and Figure 1, Figure 2).

$$
E_{\text {номо }}-E_{\text {LUмО }}=-0.12081_{\text {аu }}=-3.286 \mathrm{eV}
$$

Since the HOMO-LUMO energy separation of the complex may be considered a simple indicator of kinetic stability it can be said that the supramolecular complex which has: $E_{\text {НОмО }}-E_{L U M O}=3.286 \mathrm{eV}$, appears to possess a low kinetic stability and a high chemical reactivity [11]. The dipole moment value is appearing as a result of the formation of the complex (Table 3).

In this complex 5-HTP is not interacting directly with ATP as in a binary complex previously described. Another difference for the two complexes is the fact that the association energy of the tripartite complex is very

Table 1. Stabilization energy of the molecules and of the complex at the B3LYP/6-31G* level.

\begin{tabular}{cccccc}
\hline Results & ATP & 5HTP & DHEA & ATP-5HTP-DHEA & $\Delta E_{\text {assoc }}=E_{A B C}-E_{A}-E_{B}-E_{C}$ (a.u.) \\
\hline Total Energy (a.u.) & -2665.5171 & -761.3439 & -891.282 & -4320.6621 & -2.5191 \\
\hline
\end{tabular}

Table 2. Total atomic charge on selected atoms in the molecular components and in the association complex, from a DFT Mulliken population (B3LYP) analysis.

\begin{tabular}{|c|c|c|c|c|c|c|c|c|c|c|c|}
\hline Atom & $\begin{array}{l}\text { Frag } \\
\text { ATP }\end{array}$ & Complex & $\begin{array}{l}\text { Var. } \\
\Delta \mathrm{Q}\end{array}$ & Atom & $\begin{array}{l}\text { Frag. } \\
\text { DHEA }\end{array}$ & Complex & $\begin{array}{l}\text { Var. } \\
\Delta \mathrm{Q}\end{array}$ & Atom & $\begin{array}{c}\text { Frag } \\
5 \text { HTP }\end{array}$ & Complex & $\begin{array}{l}\text { Var. } \\
\Delta \mathrm{Q}\end{array}$ \\
\hline $\mathrm{H}_{102}$ & 0.351 & 0.407 & 0.056 & $\mathrm{O}_{47}$ & -0.421 & -0.516 & -0.095 & $\mathrm{O}_{25}$ & -0.560 & -0.335 & -0.225 \\
\hline \multirow[t]{4}{*}{$\mathrm{O}_{111}$} & -0.375 & -0.703 & -0.328 & $\mathrm{H}_{74}$ & 0.147 & 0.166 & +0.019 & $\mathrm{O}_{22}$ & -0.635 & -0.659 & -0.024 \\
\hline & & & & $\mathrm{H}_{63}$ & 0.132 & 0.186 & +0.054 & & & & \\
\hline & & & & $\mathrm{H}_{67}$ & 0.113 & 0.208 & +0.095 & & & & \\
\hline & & & & $\mathrm{H}_{70}$ & 0.121 & 0.142 & +0.021 & & & & \\
\hline
\end{tabular}


Table 3. Reactivity parameters computed at the B3LYP/6-31G* level.

\begin{tabular}{ccccc}
\hline Reactivity Parameter & ATP & 5HTP & DHEA & ATP-5HTP-DHEA \\
\hline HOMO (a.u.) & -0.20603 & -0.20132 & -0.24098 & -0.16755 \\
LUMO (a.u.) & -0.08660 & -0.01510 & -0.02440 & -0.04674 \\
$\mu$ (D) & 7.54 & 3.4890 & 2.74 & 11.1781 \\
\hline
\end{tabular}

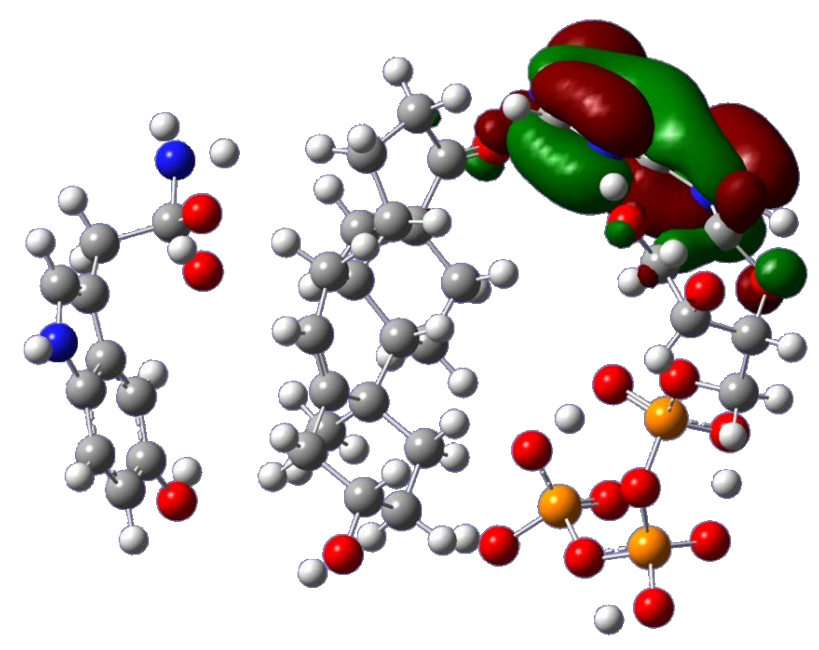

Figure 1. HOMO in HF/6-31 g triple complex.

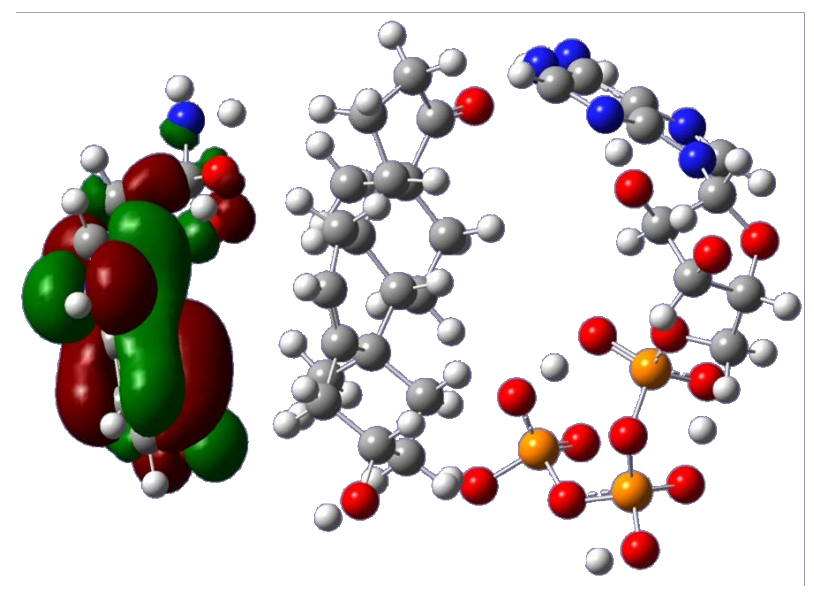

Figure 2. LUMO in HF/6-31 g triple complex.

high at this computational level compared to that of the binary complex. This is in favor of the possible existence of such a complex. Of course, this modeling corresponds to data obtained at 0 degree $\mathrm{K}$ and the presence of water as a solvent would heavily perturb the structure.

\section{Conclusions}

- From these B3LYP calculations, an association complex involving ATP, 5-HTP and DHEA, would have a large stabilization energy.

- The present theoretical study on the electronic changes brought about by complexation leads to the hypothesis that an enhancement in the biological action of ATP, 5-HTP, and/or DHEA, could result from their interaction. This hypothesis should now be reinforced by the experimental observation of an interaction between those three molecules. 


\section{References}

[1] Lerner, D.A., Weinberg, J. and Balaceanu-Stolnici, C. (2002) Ab Initio and Semiempirical Molecular Orbital Calculations on DHEA I. The Electronic Structure. Revue Roumaine de Chimie, 47, 893-899.

[2] Lerner, D.A., Weinberg, J., Cimpoesu, F. and Balaceanu-Stolnici, C. (2006) Theoretical Study of DHEA: Comparative HF and DFT Calculations of the Electronic Properties of a Complex between DHEA and Serotonin. Journal of Molecular Modeling, 12, 146-151. http://dx.doi.org/10.1007/s00894-005-0007-9

[3] Weinberg, J., Cimpoesu, F. and Lerner, D.A. (2009) The Association of Dehydro-Epiandrosterone and Adenosine Triphosphate Acid: A DFT Study of Interactions between Prototypic Biologically Active Molecules. Journal of Molecular Structure THEOCHEM, 912, 32-37. http://dx.doi.org/10.1016/j.theochem.2009.04.040

[4] Weinberg, J. and Lerner, D.A. (2013) Theoretical Study of 5-HTP. Potential New Drug Resulting from the Complexation of 5-HTP with ATP. Journal of Computational Chemistry, 1, 1-4. http://dx.doi.org/10.4236/cc.2013.11001

[5] Allinger, N.L. (1977) Conformational Analysis. 130. MM2. A Hydrocarbon Force Field Utilizing V1 and V2 Torsional Terms. Journal of the American Chemical Society, 99, 8127-8134. http://dx.doi.org/10.1021/ja00467a001

[6] Frisch, M.J., Trucks, G.W., Schlegel, H.B., Scuseria, G.E., Robb, M.A., Cheeseman, J.R., Scalmani, G., Barone, V., Mennucci, B., Petersson, G.A., Nakatsuji, H., Caricato, M., Li, X., Hratchian, H.P., Izmaylov, A.F., Bloino, J., Zheng, G., Sonnenberg, J.L., Hada, M., Ehara, M., Toyota, K., Fukuda, R., Hasegawa, J., Ishida, M., Nakajima, T., Honda, Y., Kitao, O., Nakai, H., Vreven, T., Montgomery Jr., J.A., Peralta, J.E., Ogliaro, F., Bearpark, M., Heyd, J.J., Brothers, E., Kudin, K.N., Staroverov, V.N., Kobayashi, R., Normand, J., Raghavachari, K., Rendell, A., Burant, J.C., Iyengar, S.S., Tomasi, J., Cossi, M., Rega, N., Millam, J.M., Klene, M., Knox, J.E., Cross, J.B., Bakken, V., Adamo, C., Jaramillo, J., Gomperts, R., Stratmann, R.E., Yazyev, O., Austin, A.J., Cammi, R., Pomelli, C., Ochterski, J.W., Martin, R.L., Morokuma, K., Zakrzewski, V.G., Voth, G.A., Salvador, P., Dannenberg, J.J., Dapprich, S., Daniels, A.D., Farkas, O., Foresman, J.B., Ortiz, J.V., Cioslowski, J. and Fox, D.J. (2009) Gaussian 09, Revision A.1. Gaussian, Inc., Wallingford.

[7] (a) Cramer, C.J. (2002) Essentials of Computational Chemistry. Theories and Models. Wiley, New York.

(b) Rahman, M.K., Nagatsu, T., Sakurai, T., Hori, S., Abe, M. and Matsuda, M. (1982) Effect of Pyrizdoxal Phosphate Deficiency on Aromatic L-Amino Acid Decarboxylase Activity with L-DOPA and L-5-Hydroxytryptophan as Substrates in Rats. The Japanese Journal of Pharmcology, 32, 803-811. http://dx.doi.org/10.1254/jip.32.803

(c) Bouchard, S., Bousquet, C. and Roberge, A.G. (1981) Characteristics of Dihydroxyphenylalanine/5-Hydroxytryptophan Decarboxylase Activity in Brain and Liver of Cat. Journal of Neurochemistry, 37, 781-787.

(d) 5-HTP: Uses, Side Effects, Interactions and Warnings-WebMD. Archived from the Original on 16 November 2009.

[8] Fukui, K., Yonezawa, T. and Nagata, C. (1954) An Investigation into the Reactivity of Isotetralin. Bulletin of the Chemical Society of Japan, 27, 423. http://dx.doi.org/10.1246/bcsj.27.423

[9] Fukui, K., Yonezawa, T. and Nagata, C. (1957) Interrelations of Quantum-Mechanical Quantities Concerning Chemical Reactivity of Conjugated Molecules. The Journal of Chemical Physics, 26, 831. http://dx.doi.org/10.1063/1.1743416

[10] Fleming, I. (1976) Frontier Orbitals and Organic Chemical Reactions. Wiley, London.

[11] Yazici, S., Albayrak, C., Gümrükçüoğlu, I.E., Senel, I. and Büyükgüngör, O. (2011) Experimental and Density Functional Theory (DFT) Studies on (E)-Acetyl-4-(4-Nitrophenyldiazenyl) Phenol. Journal of Molecular Structure, 985, 292298. http://dx.doi.org/10.1016/j.molstruc.2010.11.009 
Scientific Research Publishing (SCIRP) is one of the largest Open Access journal publishers. It is currently publishing more than 200 open access, online, peer-reviewed journals covering a wide range of academic disciplines. SCIRP serves the worldwide academic communities and contributes to the progress and application of science with its publication.

Other selected journals from SCIRP are listed as below. Submit your manuscript to us via either submit@scirp.org or Online Submission Portal.
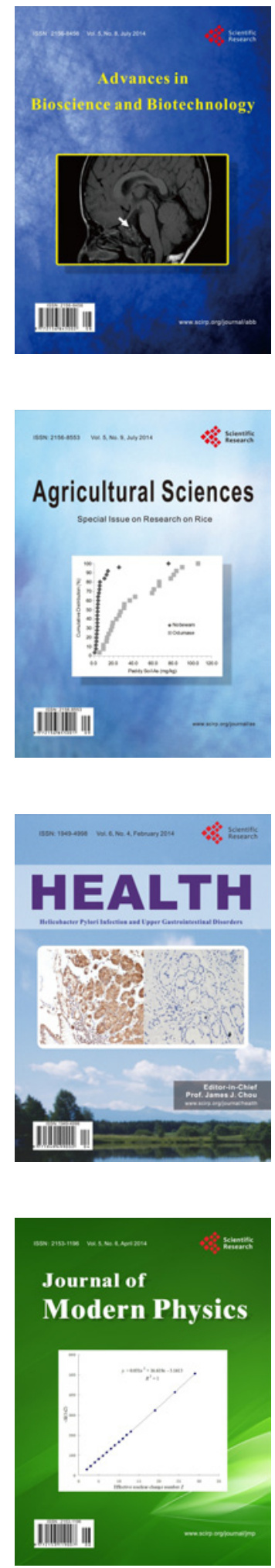
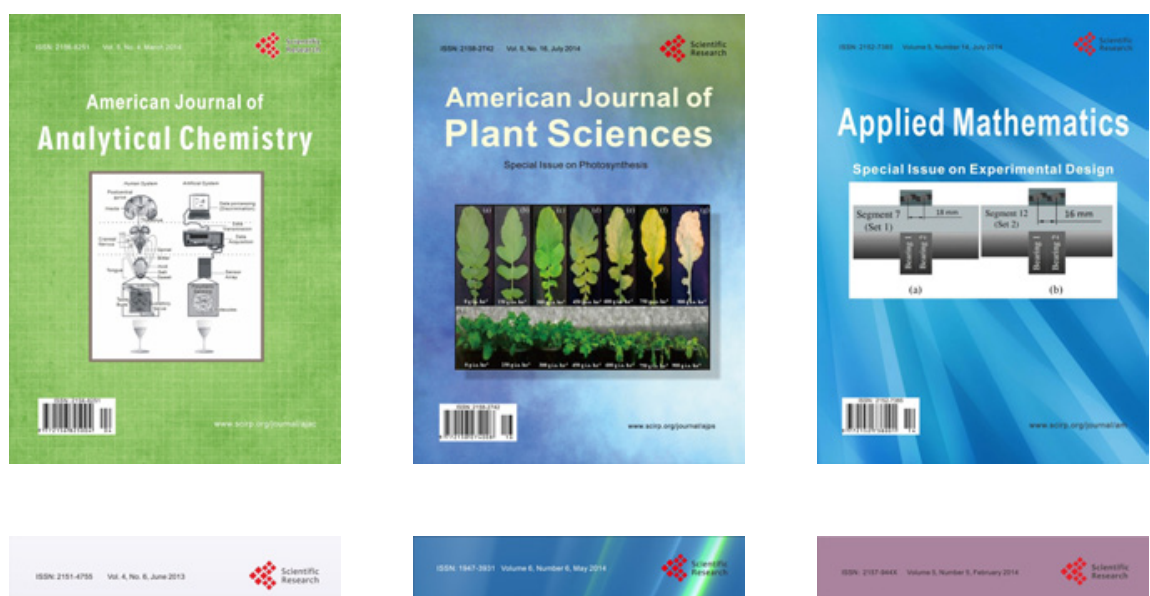

Creative Education
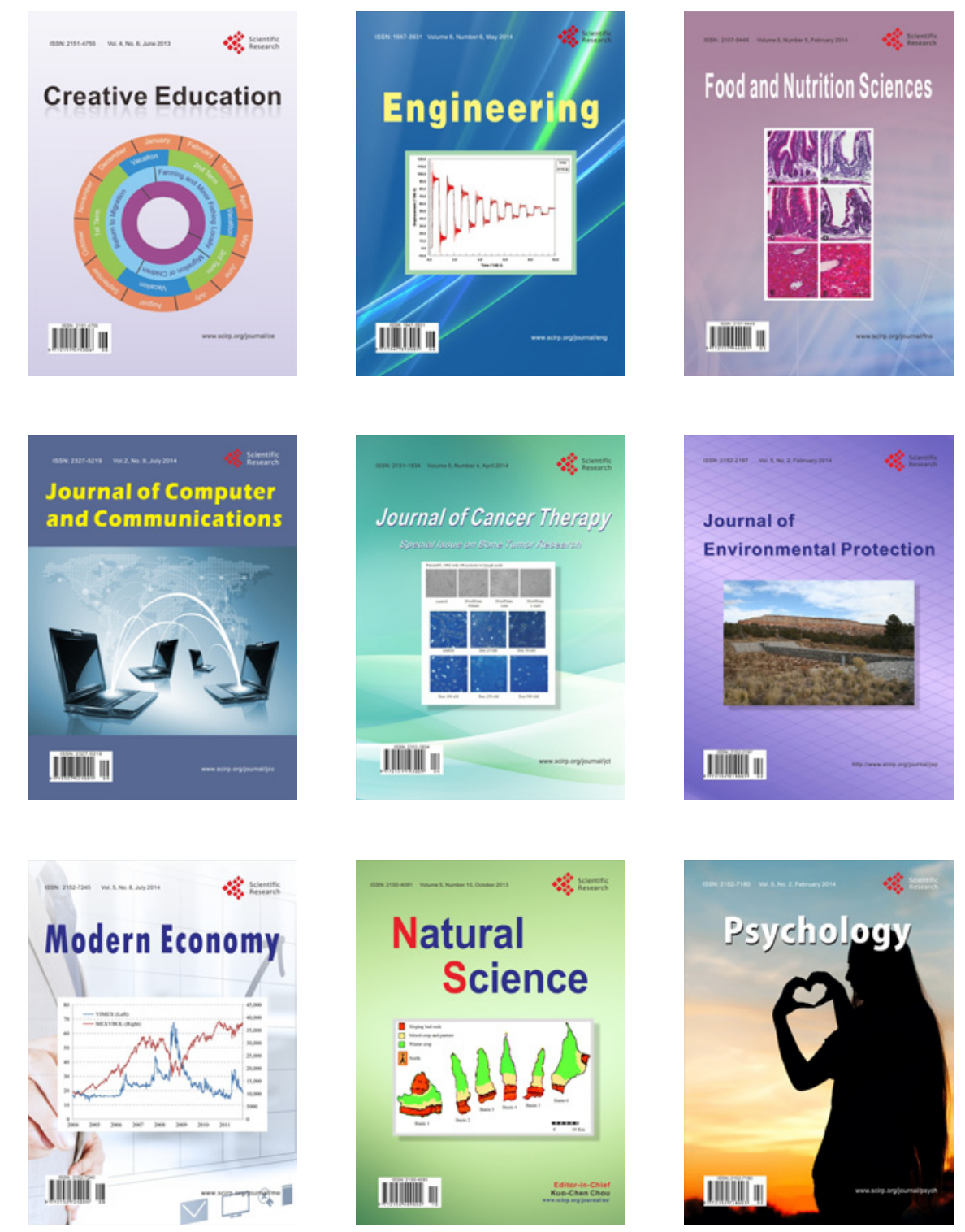